\title{
“БОЛОНСЬКИЙ ПРОЦЕС” І УКРАЇНА: РЕАЛІЇ, МІФИ І ПЕРСПЕКТИВИ
}

\author{
В. М. Ждан, В. М. Бобирьов, С. М. Білаш, А. В. Салій, О. В. Шешукова \\ Вищий держсавний навчальний заклад Украӥни "Украӥнська медична стоматологічна академія", \\ м. Полтава
}

\section{"BOLOGNA PROCESS" AND UKRAINE: REALITIES, MYTHS AND PROSPECTS}

\author{
V. M. Zhdan, V. M. Bobyryov, S. M. Bilash, A.V. Saliy, O. V. Sheshukova \\ Higher State Educational Institution of Ukraine "Ukrainian Medical Stomatological Academy", \\ Poltava
}

\footnotetext{
У статті розглянуто особливості впровадження положень Болонської декларації в Україні і труднощі, що виникають при цьому.
}

The article deals with the peculiarities of the implementation of the Bologna Declaration in Ukraine and the difficulties in doing so.

Вступ. Сучасна модель освіти склалася під впливом наукової революції XVII - XVIII ст., коли в результаті диференціації знань формується галузева наука, яка і знаходить свій прояв у системі освіти. Сама ж освіта, будучи одним із найважливіших засобів трансляції культури і соціалізації індивідів, завжди детермінується моделлю культури [3]. Сучасна трансформація культури робить обов'язковими істотні зміни в системі освіти, спонукає до пошуків нових ідей як у філософії освіти, так і в педагогіці. Одним із прикладів такого пошуку нового, у геополітичному вимірі освітнього процесу, і став так званий “Болонський процес". Для України це явище було і залишається надзвичайно актуальним, адже досягнення нових результатів у вищій освіті, подолання недоліків існуючої системи підготовки фахівців і на цій основі збереження конкурентоспроможності випускників та престижу української вищої освіти у світовому освітньому просторі можливе лише за умов упровадження нових технологій навчання. Межі “'Болонського процесу” формулюють кілька основних позицій:

- запровадження кредитно-модульної системи;

- розширення мобільності студентів і викладачів;

- запровадження кардинально нової системи контролю за якістю освіти.

Основна частина. Кредитно-модульна система (KMC) визначається для України як орієнтир побу-

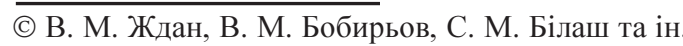

дови навчального процесу. Такій системі, як обов'язковому атрибуту Болонської декларації, надаються дві основні функції. Перша - сприяння мобільності студентів і викладачів, друга - чітке визначення обсягів проведеної студентами роботи з урахуванням усіх видів навчальної та наукової діяльності.

За роки свого функціонування КМС показала свої як позитивні, так і негативні сторони. До позитивних сторін можна віднести стимулювання студентів до активної регулярної роботи протягом семестру; вона вимагає від студента ініціативності, студенти звикають до різних форм роботи; така система $є$ більш ефективною ізменшує суб' єктивний фактор при оцінюванні. Але недоліком є те, що за умов КМС і великої кількості студентів у групах досить складно забезпечити всім студентам рівні можливості для отримання необхідних балів, сюди ж ми можемо віднести і збільшення навантаження на викладачів, а бали, накопичені студентом, не завжди говорять про його знання, а більше про його активність. Студенти, фактично, борються за кількість балів, а не за знання.

Розвиток КМС за останні десять років породив величезну кількість міфів-забобонів [2], які потребують якщо не спростування, то хоча б елементарного уточнення.

Перша хибна думка: запровадження “Болонського процесу" в Україні явище негативне і призведе до руйнації освітньої системи України і нищення їі здобутків. 
Якщо тільки ми спробуємо замінити дефініцію “Болонський процес" на “удосконалення системи освіти” відразу спаде одіозність самого цього явища. У сучасній Україні навряд чи знайдеться хтось, хто б заперечував би потребу реформування системи освіти. Тут важливо зрозуміти, що у глобальному контексті світова освітня система перебуває у кризовому стані, оскільки залежно від своїх індивідуальних особливостей знаходиться у перехідному періоді у зв'язку зі зміною постіндустріального суспільства на комунікаційне, інформаційне тощо. Саме у такому контексті удосконалення будь-якої освітньої системи не тільки бажане, а просто необхідне. Відповідно, те, що ми сьогодні називаємо "Болонським процесом", $\epsilon$ відповіддю освітньої системи Свропи на втрату конкурентоспроможності порівняно 3 американською системою освіти.

Сама відсутність бажання удосконалюватись у системі української освіти суперечить як здоровому глузду, так і може демонструвати умисне бажання прискорити її остаточне банкрутство.

Одне $з$ хибних тверджень полягає у тому, що викладачі основними ознаками Болонського процесу вважають введення кредитно-трансферої системи із новою системою оцінювання і упровадження диплома єдиного зразка.

У таких твердженнях може полягати основна і найголовніша помилка. Адже основна мета навчання не оцінювання, а “якість освіти”. Кількість модулів чи система оцінювання - це речі похідні, які не мають вирішального стратегічного значення. Саме гонитва за кількісним показником, а не за якісним, призводить до того, що у боротьбі за професійне зростання випускник українського вишу суттєво програє європейцю або американцю. Покращення якості навчання, насамперед, повинно полягати не в особливостях формування навчального плану, а у способі викладання конкретної дисципліни. Тобто поки у середньопересічного доцента не забрати його пожовклий від часу конспект, ніякого покращення не відбудеться. Ми повинні розуміти, що контроль за якістю навчання здійснюється на

\section{Література}

1. Болонський процес у фактах і документах / [упорядники: М.Ф. Степко, Я. Я. Болюбаш, В. Д.Шинкарук та ін.]. - К., 2003.

2. Згуровський М. Вища освіта в Україні: реалії, тенденції, перспективи розвитку / М. Згуровський. -К., 1996. рівні викладач-студент, але найбільше успішність цієї роботи залежить від професійно-інтелектуальних здібностей викладача та інтелектуального потенціалу того, хто здобуває знання.

Таким чином, якщо не відбудуться зміни у мисленні викладача, то жодні нормативні акти не забезпечать запуск цього процесу. Тому успіх у боротьбі за якість навчання не пов'язаний $з$ жодними загальнодержавними деклараціями. У цьому контексті перехід до зовнішнього тестування, запровадження кредитно-транферної системи можна вважати організаційно додатковими заходами, які покращуватимуть якість навчання, але не визначатимуть його.

Побоювання серед фахівців викликає те, що мобільність студентів може призвести до відтоку студентів та скорочення вишів.

Якщо під мобільністю ми будемо розуміти можливість здобуття освіти в межах одного напрямку в різних вишах європейського освітнього простору, то це може означати, що студенти і викладачі матимуть перспективу для самореалізації в країнах СС та США. В силу об'єктивних причин освітня система України суттєво програє іншим, а тому відтік студентської маси може бути цілком логічним і передбачуваним.

Інтеграція в освітній простір Європи має проходити на рівні конкуренції ідей, а не на рівні порівняння економічних систем у випадку вступу до ЄС. Обмін ідеями за будь-яких обставин приводить до неминучого збагачення, причому обох сторін.

Скорочення кількості навчальних закладів - це взагалі проблема, яка є насущною і злободенною. Адже кількість вищих навчальних закладів в Україні перевищує усі розумні межі. Станом на 2013 р. кількість ВНЗ в Україні дорівнює 823, а це саме той випадок, коли кількість згубно впливає на якість.

Висновки. I на завершення хотілося б зазначити, що успіх будь-якої реформи визначається саме розумінням кінцевої мети процесу і сприйняттям його більшістю співробітників об'єкта реформування. Принципи заміни вивісок і спрощене копіювання стандартів інших систем ніколи не приводить до успіху.

3. Нарижный Ю. А. Культура и философия эпохи постмодерна / Ю. А. Нарижный. - Днепропетровск : ДГУ, 2008. $-478 \mathrm{c}$. 